\title{
Effect of Different Pretreatments on Palm Kernel Shell And Low-rank Coal during Co-gasification
}

\author{
Razi Ahmad ${ }^{1,4 *}$, Mohd Azlan Mohd Ishak ${ }^{2,3}$, Nur Nasulhah Kasim ${ }^{1}$ and Khudzir Ismail ${ }^{1,3}$ \\ ${ }^{1}$ Faculty of Applied Sciences, Universiti Teknologi MARA, Shah Alam, Selangor, Malaysia \\ ${ }^{2}$ Faculty of Applied Sciences, Universiti Teknologi MARA, Perlis Branch, Arau, Perlis, Malaysia \\ ${ }^{3}$ Coal and Biomass Energy Research Group, Universiti Teknologi MARA, Perlis Branch, Arau, Perlis, Malaysia \\ ${ }^{4}$ School of Environmental Engineering, Universiti Malaysia Perlis, Perlis, Malaysia
}

*Corresponding author: Razi Ahmad, Faculty of Applied Sciences, Universiti Teknologi MARA, Shah Alam, Selangor, Malaysia.

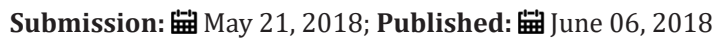

\begin{abstract}
In this study, co-gasification of different types of pretreatments on palm kernel shell (PKS) and low-rank Mukah Balingian (MB) coal was carried out in a fixed bed reactor. First pretreatment involved torrefaction of $\mathrm{PKS}$ at $270^{\circ} \mathrm{C}$ and preheating of $\mathrm{MB}$ coal at $250^{\circ} \mathrm{C}$ for $1 \mathrm{hr}$. For second pretreatment, both samples were irradiated using microwave oven at $450 \mathrm{~W}$ for $8 \mathrm{~min}$. The effect of various blending combinations of both pretreated samples were investigated towards product yields (gas, tar and char) and composition (gas and tar). Results showed that, all pretreated blended samples produced higher gas yield and lower tar and char yield than the untreated blended samples. This was due to low moisture and oxygenated compounds of the pre-treated samples prior to gasification. Torrefied PKS and preheated MB blending produced the highest gas yield and lowest tar yield. Moreover, the torrefied PKS and preheated MB blending was the best combination which produced the highest $\mathrm{H}_{2}+\mathrm{CO}$ and the lowest $\mathrm{CH}_{4}$ and $\mathrm{CO}_{2}$ composition. Tar composition of the pre-treated blending samples indicated the obvious reduction of phenol and carbonyl; however, promoted the aromatic and aliphatic alkane. This existence affected from the decomposition of cellulose and hemi-cellulose and partial decomposition of lignin throughout the pretreatment stage. In addition, the pre-treatment types seemed to have significance impact on the distribution and composition of product yields during co-gasification..
\end{abstract}

Keywords: Palm kernel shell; Mukah Balingian; Low rank coal; Pretreatment; Co-gasification

\section{Introduction}

In recent years, the increasing emission of $\mathrm{CO}_{2}, \mathrm{SO}_{\mathrm{x}}$ and $\mathrm{NO}_{\mathrm{x}}$ has become a concern on the utilization of the world energy [1]. Coal remains the world's leading source of power, providing a quarter of our primary energy and more than $40 \%$ of our electricity due to its low cost [2]. In the midst of limited availability of fossil fuels and high level of air pollution, energy efficient technologies are gaining importance and gasification being highly efficient technology, has received significant attention [3]. Coal gasification is the cleanest route in coal utilization compared with the direct combustion (through coal-fired power plants and industrial boilers) and coking. In China, coal gasification accounts for $5 \%$ of the total coal consumption. This technology is essential in chemical industry, oil refining, power generation and metallurgical industries due to its efficient and clean coal conversion [4]. Currently, coal is the main feedstock in gasification and is expected to be applied as the energy resource for many decades ahead. However, this direction difficult to achieve due to the increasing in energy demand that had caused the shortage supply and reducing of high rank coal [5]. Consequently, one of the approaches is to utilize the abundant low rank coal and biomass in gasification.

The low rank coals are almost partial of the world's entire coal deposits compared to the high rank coal [6]. The usage of low rank coals in thermal conversion is economical, due to its low pricing. However, low rank coal as a substitute to the high rank coal, has several limitations i.e. low calorific value and high moisture and oxygen content [6]. These drawbacks can be minimized by using the pretreated or upgraded low rank coal in gasification [7]. Similarly, the utilization of biomass which is a renewable and environmental friendly resource during gasification imposed several problems. Untreated biomass has relatively low energy, high moisture and oxygenated compound, hygroscopic behavior and poor grind ability [8]. Accordingly, the pretreated or torrefied biomass which has been improved in energy density, hydrophobicity and grind ability overcome the weakness of untreated biomass, then driven to be applied in thermo-chemical conversion [9]. 
Biomass generally has a high content of hydrogen $(\mathrm{H})$, making it suitable to be blend with coal which has low content of H. Further, the alkali and alkaline earth metals (AAEM) in biomass catalyze the gasification of char resulting from coal pyrolysis. Equally the high silica $\left(\mathrm{SiO}_{2}\right)$ content in coal acts as an effective catalyst for tar cracking to lighter hydrocarbon in thermal conversion [10]. However, biomass as gasification feed stock, has higher oxygen and moisture content which contributes to the disadvantage of low energy density than coal. Therefore, co-gasification of biomass and coal can be alternative to single biomass or coal gasification as it has benefits and may stabilize their weakness towards each other [11].

Co-gasification has been investigated by several researchers. Krerkkaiwan et al. [12] found the synergistic effect in terms of higher gas yield, lower tar and char yield at 50\% biomass blending ratio with coal. Howaniec \& Smolinski [13] reported that the cogasification increased total gas yield and $\mathrm{H}_{2}$ yield compared to individual gasification. Yuan et al. [14] stated that there were synergistic effects in the decreasing of char yield and increase of gas yield in co-conversion of coal/biomass mixtures. Consequently, the synergistic between biomass and coal co-gasification increases the gas yield, gasification efficiency and reactivity of char whereas reduces the tar yield. Most of the blending in co-gasification utilized untreated biomass and coal.

Dudynski etal. [15] reported that effective and stable gasification with lower tar production was obtained from torrefied pelletsin comparison to untreated biomass and suggested that pretreated biomass more appropriate to be applied for co-gasification. Moreover, the blending of pretreated biomass and sub-bituminous coal in co-gasification was found to minimize the formation of agglomerates in fluidized bed reactor [16]. Kuo et al. [17] produced higher syngas yield using torrefied bamboo in fixed bed reactor system. Indeed, torrefaction creates the gasification behavior of biomass approach to that of coal where the $\mathrm{H}_{2}$ composition in syngas of torrefied biomass comparable is with coal. Therefore, the pretreated feedstock which had been improved in their properties enhances the gasification performance $\mathrm{andH}_{2}$ production in syngas [18]. The main purpose of this study was to investigate the effect of different types of pretreated PKS and MB coal blending duringcogasification.The influenceon co-gasification were discovered in terms of product yields (char, tar and gas) and product composition (tar and gas).

\section{Method}

\section{Materials}

PKS as biomass sample was obtained from United Oil Palm Mill Sdn. Bhd., Nibong Tebal and Penang, Malaysia. PKS sample was crushed and sieved through finer screen to obtain particle sizes in the range of 200 to $400 \mu \mathrm{m}$. MB coal, which is classified as Malaysian low rank sub-bituminous coal from Sarawak, Malaysia was used as the coal sample in this study. The untreated MB coal was pulverized and sieved through finer screen to obtain particle sizes of less than $212 \mu \mathrm{m}$. The PKS and MB samples were dried in an oven overnightat $105{ }^{\circ} \mathrm{C}$ and finally stored in an air-tight container until the analyses were carried out. The torrefied PKS was produced at $270{ }^{\circ} \mathrm{C}$ for $1 \mathrm{~h}$ and the preheated MB was produced at $250{ }^{\circ} \mathrm{C}$ for $1 \mathrm{~h}$ using fixed bed reactor. While, the PKS and MB microwave irradiated was produced at $450 \mathrm{~W}$ with $8 \mathrm{~min}$ processing time using modified Samsung microwave. The pre-treated PKS and pre-treated MB coal were prepared and selected according to our previous work [19].

\section{Gasification experiment}

The co-gasification of PKS and MB were carried out using a vertical fixed bed reactor with an internal diameter of $60 \mathrm{~mm}$ and $300 \mathrm{~mm}$ in height at an ambient pressure. An electric furnace surrounding the reactor was use to heat the reactor. A schematic diagram of the experimental set-up is shown in Figure 1.

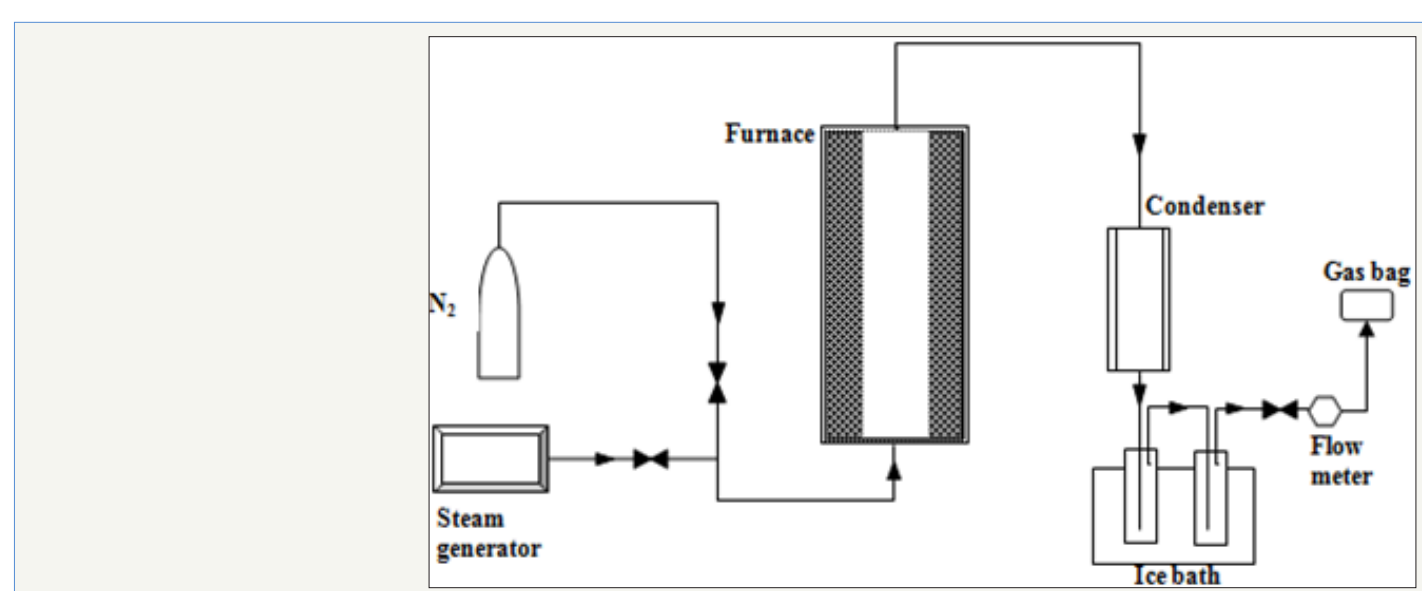

Figure 1: Schematic diagram of a fixed bed reactor system used in this study.

Approximately $5 \mathrm{~g}$ of sample (biomass blending ratio=50\%) was weighed and positioned inside the reactor. The reactor was flushed with nitrogen gas for $10 \mathrm{~min}$ before the experiment. Then, the samples were heated to the desired gasification temperature with heating rate of $50^{\circ} \mathrm{C} / \mathrm{min}$. A nitrogen flow rate of $0.5 \mathrm{~L} / \mathrm{min}$ was remained constant to create an inert atmosphere inside the reactor. After the reactor reached the preferred gasification temperature, the steam that was produced from the steam generator was introduced into the reactor, while the nitrogen flow was stopped. The steam gasification of the sample was held for $45 \mathrm{~min}$. 
The volatile product and steam which left the reactor from the upper side were condensed in a tar trap. The tar trap consists of two bottles placed in the ice bath. The non-condensable gases passed through a cotton wool and silica gel to remove out the remaining moisture. Then, the dry gas was collected in a gas bag every $15 \mathrm{~min}$ from the beginning of steam gasification. When the process ended, the furnace was turned off and the reactor was left to cool to the ambient temperature. The final weight of the remained solid, which is defined as char was measured once it reached the room temperature. The condensable products which consist of tar and water fraction were dissolved in dichloromethane solvent. Later, the dissolved tar was separated and measured from the water fraction using liquid extraction method. The gas yield was calculated by difference based on the total mass balances considering the tar and char yield.

The gas that was collected in gas bag was analysed offline by portable gas analyser GA5000. The content of $\mathrm{CH}_{4}, \mathrm{CO}_{2}, \mathrm{O}_{2}$ and balance gas was measured by gas analyser. The balance gas was assumed as $\mathrm{H}_{2}+\mathrm{CO}$ since other gases such as $\mathrm{C}_{2} \mathrm{H}_{4}, \mathrm{C}_{2} \mathrm{H}_{6}$ and $\mathrm{C}_{3} \mathrm{H}_{8}$ exist in lower concentrations [20]. The chemical compound of tar was analysed by gas chromatography-mass spectrometry (GC-MS) model Agilent 6890N equipped with a HP-5MS capillary column ( $30 \mathrm{~m}$ x $250 \mu \mathrm{m} \times 0.25 \mu \mathrm{m}$ nominal). The tar sample of $1 \mu \mathrm{L}$ was injected into the injector using auto sampler. The flow rate of helium as carrier was set at $1 \mathrm{ml} / \mathrm{min}$. The GC oven temperature was controlled with the programme as follows: (i) $50{ }^{\circ} \mathrm{C}$ hold for $3 \mathrm{~min}$, (ii) $50{ }^{\circ} \mathrm{C}$ to $180{ }^{\circ} \mathrm{C}$ at a rate of $6{ }^{\circ} \mathrm{C} / \mathrm{min}$ and (iii) $180{ }^{\circ} \mathrm{C}$ to $240{ }^{\circ} \mathrm{C}$ rate of $8{ }^{\circ} \mathrm{C} / \mathrm{min}$ and held for $30 \mathrm{~min}$. The sample blending in co-gasification was labelled with the following code: (i) PKS untreated + MB untreated as PKS Un + MB Un, (ii) PKS torrefied +
MB preheated as PKS To + MB Pr, (iii) PKS torrefied + MB microwave irradiation as PKS To + MB Mi, (iv) PKS microwave irradiation + MB preheated as PKS Mi + MB Pr, and (v) PKS microwave irradiation + MB microwave irradiation as PKS Mi + MB Mi.

\section{Results and Discussion}

\section{Effect of co-gasification of different type pretreatments on product yield}

Figure 2 presents the results obtained in term of product yield (char, tar and gas) during the experiment under optimise condition at gasification temperature of $767{ }^{\circ} \mathrm{C}$, biomass blending ratio of $52 \%$ and steam flow rate of $55 \mathrm{ml} / \mathrm{min}$. All type of mixed pre-treated sample produced higher gas yield than the untreated sample. The gas yield increased from 7.9 to $34.3 \%$ using pre-treated sample. The highest gas yield was produced using blending PKS torrefied $+\mathrm{MB}$ preheated. The production of gas yield was as followed: PKS To $+\mathrm{MB}$ Pr $>$ PKS To + MB Mi $>$ PKS Mi + MB Pr $>$ PKS Mi + MB Mi $>$ PKS Un + MB Un. The same pre-treatment method i.e. thermal pretreatment in fixed bed reactor where torrefaction and preheated for PKS and MB coal, respectively, contributed the highest gas yield. While, the mix pre-treated sample from similar microwave irradiation pre-treatment showed the lowest enhancement in gas yield associated to other mixed pre-treatment. This revealed that the blending with torrefied PKS in co-gasification showed a major influenced on gas yield rather than microwave pre-treatment of PKS and pre-treatment (preheated and microwave) of MB. Chen et al. [18] and Kuo et al. [17] demonstrated the comparable result as the gasification performance was improved significantly using torrefied biomass and was conducive in increasing gas yield.

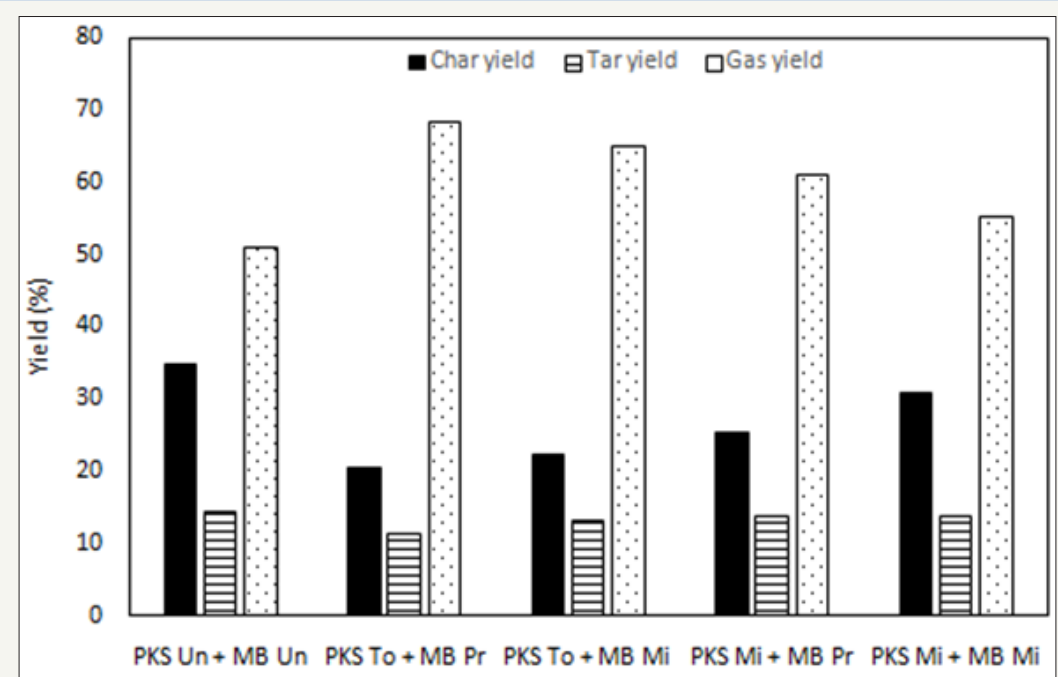

Figure 2: Effect of various mixed pretreated co-gasification on product yield.

The production of taryield was reduced for all type of mixed pretreated co-gasification compared to the untreated co-gasification. The lowest tar yield was using PKS torrefied + MB preheated which was $20.4 \%$ lower than untreated co-gasification. While, the other types of mixed pre-treated co-gasification were only reduced the tar yield in range 2.8 to $8.5 \%$ compared to the untreated co- gasification. Lowtar yield is desirable in co-gasification. Therefore, the PKS torrefied + MB preheated blending was significant for tar yield reduction in co-gasification. The char yield for all type of mixed pre-treated sample was reduced than the untreated sample in cogasification. The PKS torrefied + MB preheated showed the highest char yield reduction of $41.5 \%$. Whereas, the other type of mixed 
pre-treated co-gasification were reduced the tar yield in range of 11.5 to $36.4 \%$ compared to the untreated co-gasification. This was connected with the increased of conversion to gas and tar for pretreated feedstock. Moreover, this occurrence was affected from the low moisture and oxygenated compound of pre-treated feedstock made it soothing and ready to be converted in co-gasification. Therefore, low conversion using untreated sample produced high char yield in co-gasification.

\section{Effect of various types of mixed pretreatments co- gasification on gases composition}

Coal and biomass co-gasification produce gases such as $\mathrm{H}_{2}$, $\mathrm{CO}, \mathrm{CO}_{2}$ and $\mathrm{CH}_{4}$. The production of gases in co-gasification involves several chemical reactions. The primary devolatisation which is pyrolysis reaction (Eq. 1) and tar cracking and reforming reaction (Eq. 2) involved in early stage of co-gasification [21,22]. + Tar + Gases

$$
\text { Tar }+\mathrm{H}_{2} \mathrm{O} \longrightarrow \text { Gases }\left(\mathrm{H}_{2}, \mathrm{CO}, \mathrm{CO}_{2}, \mathrm{CH}_{4}, \mathrm{CnHm}\right) \text { (Eq. 2) }
$$

Figure 3a-3c shows the effect of various mixed pretreated cogasification on individual gas composition within $45 \mathrm{~min}$ reaction time for $\mathrm{CH}_{4}, \mathrm{CO}_{2}$ and $\mathrm{H}_{2}+\mathrm{CO}$, respectively. Beside, Figure 4 shows the overall gases composition of co-gasification on various mixed pretreated feedstock. As seen in Figure 3a, the $\mathrm{CH}_{4}$ composition increased from $15 \mathrm{~min}$ to $30 \mathrm{~min}$, then decreased at $45 \mathrm{~min}$ reaction time for all co-gasification experiment. All type of mixed pretreated sample showed increment between 17.5 to $24.3 \%$ at $15 \mathrm{~min}$ compared to the co-gasification of untreated sample. The overall gas composition on $\mathrm{CH}_{4}$ showed that the co-gasification of PKS To + MB Mi, PKS Mi + MB Pr and PKS Mi + MB Mi enhanced the $\mathrm{CH}_{4}$. While, the co-gasification of PKS To + MB Pr produced similar total composition of $\mathrm{CH}_{4}$ as untreated sample. Higher $\mathrm{CH}_{4}$ mean, the co-gasification of pretreated sample able to convert the heavy hydrocarbon in tar yield to light hydrocarbon gas as $\mathrm{CH}_{4}$.

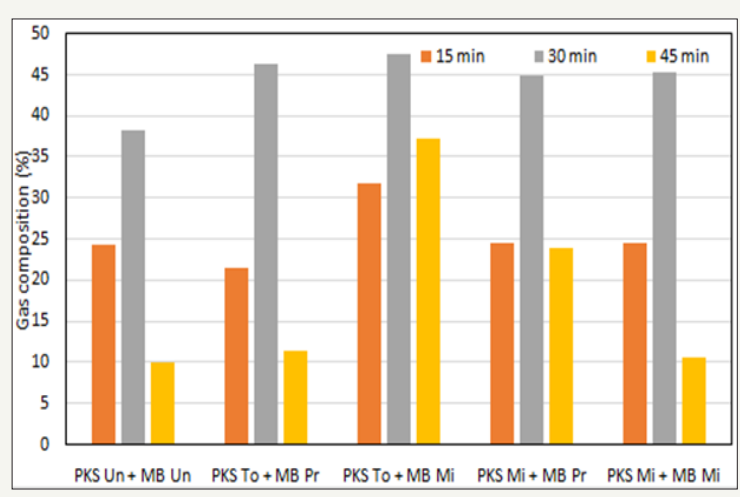

a.

$\mathrm{CH}_{4}$

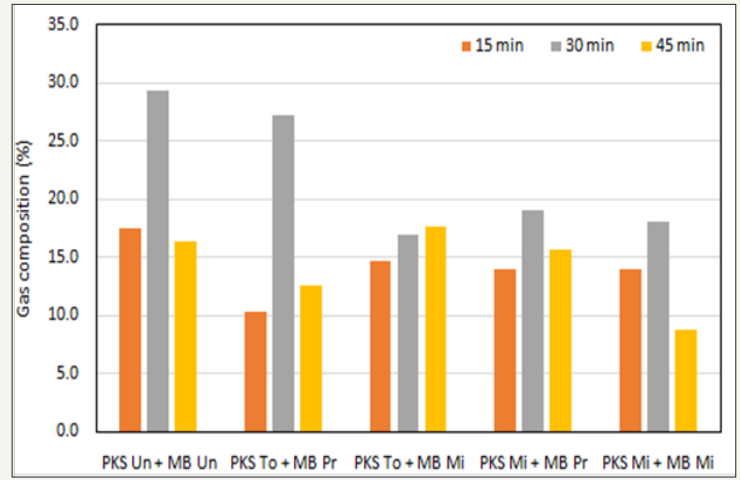

b.

$\mathrm{CO}_{2}$

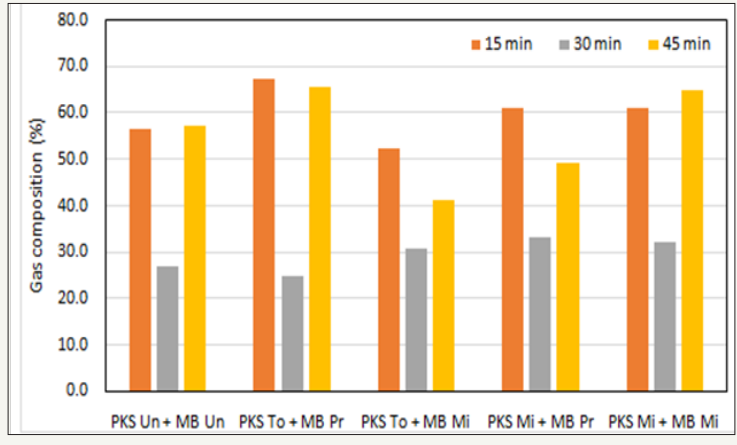

c. $\mathrm{H}_{2}+\mathrm{CO}$

Figure 3a-3c: Effect of various mixed pretreated co-gasification on product yield. 


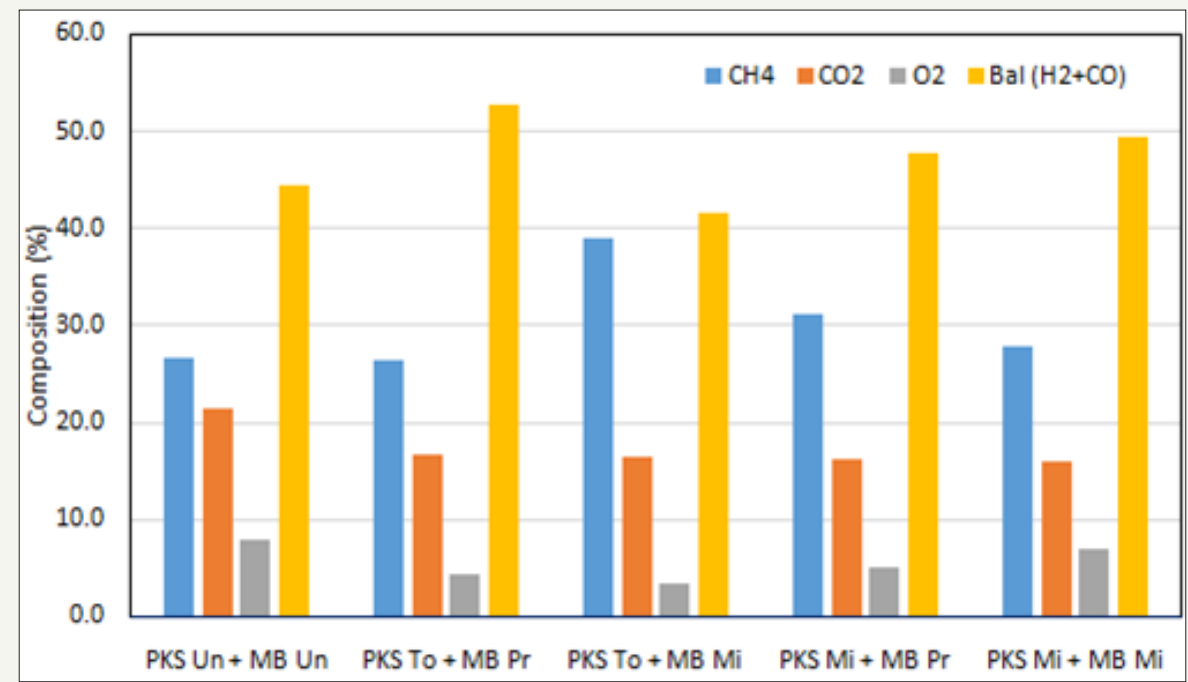

Figure 4: Effect of mixed pre-treated co-gasification on overall gases composition.

The $\mathrm{CO}_{2}$ composition showed increasing at $30 \mathrm{~min}$ for all type of co-gasification. While the trend showed decreasing at 45min, exclude PKS To + MB Mi which showed slight increased as compared to the other co-gasification. However, in overall gases composition all type of mixed pre-treated co-gasification, exhibited reduction of $22 \%$ in $\mathrm{CO}_{2}$ composition as compared to the untreated co-gasification. The $\mathrm{H}_{2}+\mathrm{CO}$ composition was between 52 to $61 \%$ at 15min except for PKS To + MB Pr which produced higher $\mathrm{H}_{2}+\mathrm{CO}$ of $67.5 \%$. These indicated that the reaction which favours production of $\mathrm{H}_{2}+\mathrm{CO}$ was greater with steam gasification at $15 \mathrm{~min}$. At these stages, the chemical reactions involved were preferred on watergas reaction (Eq. 3) and steam reforming reaction (Eq. 4).

$$
\begin{aligned}
& \mathrm{C}+\mathrm{H}_{2} \mathrm{O} \longrightarrow \mathrm{CO}+\mathrm{H}_{2} \\
& \mathrm{CH}_{4}+\mathrm{H}_{2} \mathrm{O} \longrightarrow \mathrm{CO}+3 \mathrm{H}_{2}
\end{aligned}
$$

However, at $30 \mathrm{~min}$ the $\mathrm{H}_{2}+\mathrm{CO}$ composition was the lowest composition as compared to $\mathrm{CO}_{2}$ and $\mathrm{CH}_{4}$ composition for all type of co-gasification. These were directed from the water-gas shift reaction (Eq. 5) and methanation reaction (Eq. 6) which enhanced the production of $\mathrm{CO}_{2}$ and $\mathrm{CH}_{4}$ respectively.

$$
\begin{aligned}
& \mathrm{CO}+\mathrm{H}_{2} \mathrm{O} \longrightarrow \mathrm{CO}_{2}+\mathrm{H}_{2} \text { (Eq. 5) } \\
& \mathrm{C}+2 \mathrm{H}_{2} \longrightarrow \mathrm{CH}_{4} \text { (Eq. 6) }
\end{aligned}
$$

Whereas, the $\mathrm{H}_{2}+\mathrm{CO}$ composition increased again at $30 \mathrm{~min}$ which showed the water-gas reaction, steam reforming reaction and Bourdard reaction (Eq. 7) were preferred at this time.

$$
\mathrm{C}+\mathrm{CO}_{2} \longrightarrow 2 \mathrm{CO}
$$

The overall $\mathrm{H}_{2}+\mathrm{CO}$ composition using mixed pre-treated cogasification was higher than untreated co-gasification except for PKS To + MB Mi co-gasification. The co-gasification of PKS To + MB Pr produced the greatest $\mathrm{H}_{2}+\mathrm{CO}$ composition of $52.7 \%$. Finally, the co-gasification of PKS To + MB Pr was the best combination which produced higher $\mathrm{H}_{2}+\mathrm{CO}$ and lowers the $\mathrm{CH}_{4}$ and $\mathrm{CO}_{2}$ composition.

\section{Effect of various typesof mixed pretreatments co-gasification on tar composition}

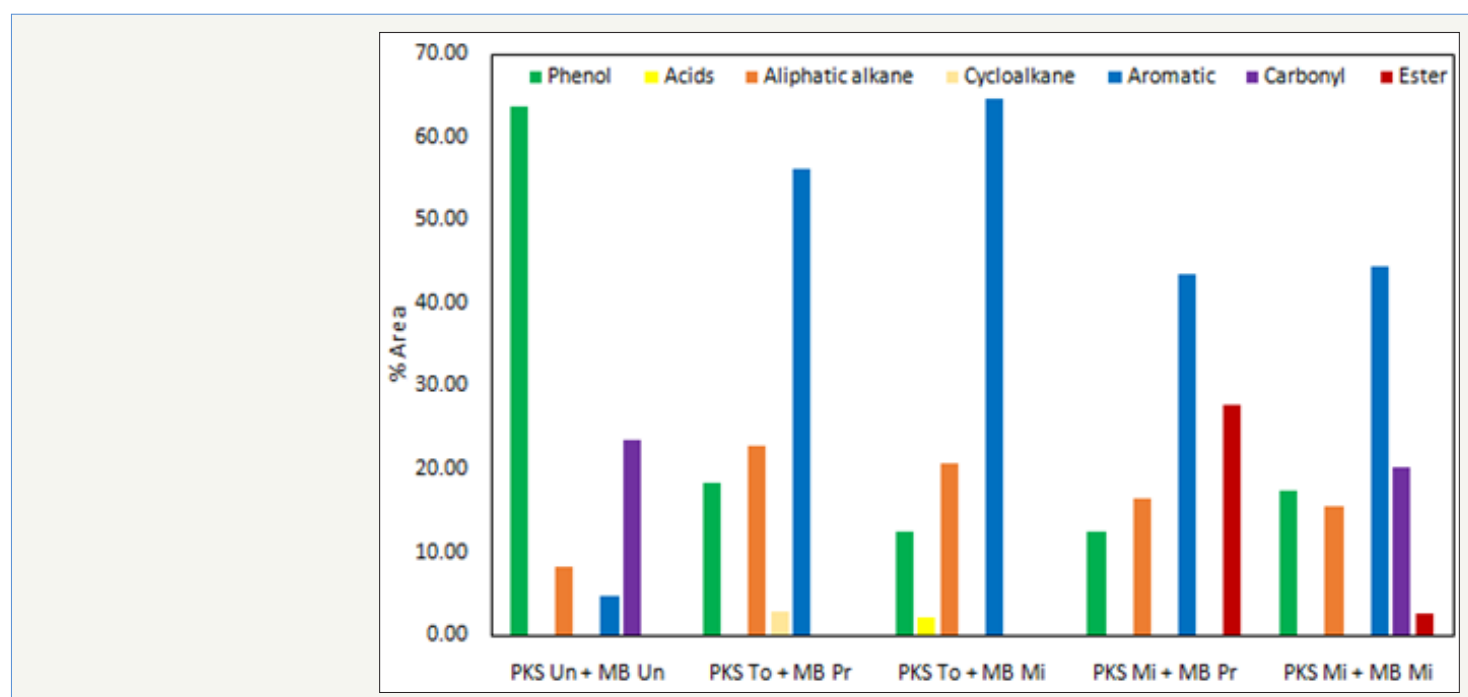

Figure 5: Effect of mixed pre-treated co-gasification on tar composition. 
Figure 5 represents the chemical composition of the tar. The figure shows the tar is essentially composed of phenol, aliphatic alkane, cycloalkane, aromatic, acid, carbonyl and ester. This result is in agreement with Krerkkaiwan et al. [12] which co-gasified rice straw with sub-bituminous coal and Tursun et al. [23] which cogasified pine saw dust with bituminous coal. The tar obtained from the co-gasification of untreated PKS and MB was largely composed of phenol with 63.5 area \%. The carbonyl, aromatic and aliphatic alkane were also composed in lesser quantity. However, the cogasification of mixed pre-treated feedstock showed the noticeable reduction of phenol and carbonyl, while, promoted the aromatic and aliphatic alkane composition.The reduction of phenol in pretreated co-gasification indicates that the effect of pretreatment had partially decomposed the lignin caused the phenol compound has been produced early during the pretreatment [24]. Therefore, the phenol content was reduced in all mixed pretreated co-gasification. Consequently, the tar can be further process in the development of coal-based bulk chemicals such as chemical fertilizers, methanol, olefins, aromatics, ethylene glycol, etc. [4].

\section{Conclusion}

Co-gasification of pretreated PKS and MB coal was investigated in a fixed bed reactor and the outcome of the different sample pretreatments blending combination were inspected on product yield and composition of gases and tar. All pretreated blended samples produced higher gas yield and lower tar and char yield than the untreated blended samples. Torrefied PKS and preheated MB coal blending was considerable for production of the highest gas yield and lowest tar yield in co-gasification. Moreover, the cogasification of torrefied PKS and preheated MB coal was the best combination which produced the highest $\mathrm{H}_{2}+\mathrm{CO}$ and the lowest $\mathrm{CH}_{4}$ and $\mathrm{CO}_{2}$ composition. The co-gasification of mixed pre-treated feed stocks revealed the clear reduction of phenol and carbonyl, besides promoted the aromatic and aliphatic alkane composition. Thus, the pre-treated feed stocks which had been enriched in their properties improved the gasification performance in term of product yield and composition.

\section{Acknowledgment}

This research project is funded by the Ministry of Higher Education, Malaysia under Fundamental Research Grant Scheme (FRGS), FRGS/1/2017/TK10/UITM/02/11. The authors acknowledge Universiti Teknologi MARA and Universiti Malaysia Perlis for providing facilities during the research work

\section{References}

1. Emami Taba L, Irfan MF, Wan Daud WAM, Chakrabarti MH (2012) The effect of temperature on various parameters in coal, biomass and COgasification: A review. Renew Sustain Energy Rev 16(8): 5584-5596.

2. Anderson R (2014) Coal gasification: The clean energy of the future? BBC News. BBC news, p. 11.

3. Heidenreich S, Foscolo PU (2015) New concepts in biomass gasification. Prog Energy Combust Sci 46: 72-95.

4. https://www.worldcoal.org/development-coal-gasificationtechnology-china
5. Mohr SH, Wang J, Ellem G, Ward J, Giurco D (2015) Projection of world fossil fuels by country. Fuel 141: 120-135.

6. Rao Z, Zhao Y, Huang C, Duan C, He J (2015) Recent developments in drying and dewatering for low rank coals. Prog Energy Combust Sci 46: $1-11$.

7. Xia W, Xie G, Peng Y (2015) Recent advances in beneficiation for low rank coals. Powder Technology 277: 206-221.

8. Chen WH, Peng J, Bi XT (2015) A state-of-the-art review of biomass torrefaction, densification and applications. Renew Sustain Energy Rev 44: 847-866.

9. Nhuchhen D, Basu P, Acharya B (2014) A Comprehensive Review on Biomass Torrefaction. Int J Renew Energy Biofuels, pp. 1-56.

10. Mallick D, Mahanta P, Moholkar VS (2017) Co-gasification of coal and biomass blends: Chemistry and engineering. Fuel 204: 106-128.

11. Brar JS, Singh K, Wang J, Kumar S (2012) Co-gasification of Coal and Biomass: A Review. Int J for Res 2012: 1-10.

12. Krerkkaiwan S, Fushimi C, Tsutsumi A, Kuchonthara P (2013) Synergetic effect during co-pyrolysis/gasification of biomass and sub-bituminous coal. Fuel Process Technol 115: 11-18.

13. Howaniec N, Smoliński A (2013) Steam co-gasification of coal and biomass - Synergy in reactivity of fuel blends chars. Int J Hydrogen Energy 38(36): 16152-16160.

14. Yuan S, Dai Z, Zhou Z, Chen X, Yu G, et al. (2012) Rapid co-pyrolysis of rice straw and a bituminous coal in a high-frequency furnace and gasification of the residual char. Bioresour Technol 109: 188-197.

15. Dudyński M, Van Dyk JC, Kwiatkowski K, Sosnowska M (2015) Biomass gasification: Influence of torrefaction on syngas production and tar formation. Fuel Process Technol 131: 203-212.

16. Strege J, Swanson M, Folkedahl B, Stanislowski J, Laumb J (2011) FischerTropsch catalyst testing in a continuous bench-scale coal gasification system. Fuel Process Technol 92(4): 757-763.

17. Kuo PC, Wu W, Chen WH (2014) Gasification performances of raw and torrefied biomass in a downdraft fixed bed gasifier using thermodynamic analysis. Fuel 117 (PART B): 1231-1241.

18. Chen W, Chen C, Hung C, Shen C, Hsu H (2013) A comparison of gasification phenomena among raw biomass, torrefied biomass and coal in an entrained-flow reactor. Appl Energy 112: 421-430.

19. Ahmad R, Ismail K, Ishak MAM, Kasim NN, Abidin CZA (2016) Pretreatment of palm kernel shell by torrefaction for co- gasification. Clean Energy and Technology Conference (CEAT 2016), pp. 1-6.

20. Berrueco C, Montané D, Matas Güell B, Del Alamo G (2014) Effect of temperature and dolomite on tar formation during gasification of torrefied biomass in a pressurized fluidized bed. Energy 66: 849-859.

21. Parthasarathy P, Narayanan KS (2014) Hydrogen production from steam gasification of biomass: Influence of process parameters on hydrogen yield - A review. Renew Energy 66: 570-579.

22. Valdés CF, Chejne F, Marrugo G, Macias RJ, Gómez CA, et al. (2016) Cogasification of sub-bituminous coal with palm kernel shell in fluidized bed coupled to a ceramic industry process. Appl Therm Eng 107: 12011209.

23. Tursun Y, Xu S, Wang G, Wang C, Xiao Y (2015) Tar formation during cogasification of biomass and coal under different gasification condition. J Anal Appl Pyrolysis 111: 191-199.

24. Ren S, Lei H, Wang L, Yadavalli G, Liu Y, et al. (2014) The integrated process of microwave torrefaction and pyrolysis of corn stover for biofuel production. J Anal Appl Pyrolysis 108: 248-253. 
Creative Commons Attribution 4.0 International License

For possible submissions Click Here

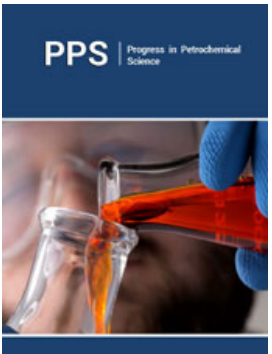

\section{Progress in Petrochemical Science}

Benefits of Publishing with us

- High-level peer review and editorial services

- Freely accessible online immediately upon publication

- Authors retain the copyright to their work

- Licensing it under a Creative Commons license

- Visibility through different online platforms 